\title{
Ontario's attractive prospect
} \begin{abstract}
fund aims to attract some of the world's leading researchers to Ontario - and keep of Research and Innovation, the Global Leadership Round in Genomics and Life Sciences fund will finance proteomics, stem-cell and genomics research, with a focus on human health. It may also support genetics and genomics research related to agriculture, environmental protection and clean technologies.
\end{abstract}

A Can\$100-million (US\$85-million) research them there. Launched by the Ontario Ministry

"With the mega-stimulus package down south [in the United States], scientists that

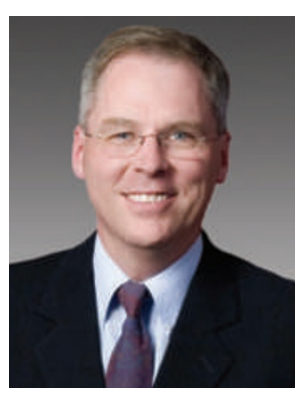

John Wilkinson wants to retain scientists.
Researchers have until the end of August to apply for the peer-reviewed competition.

Scientists say the new funding is timely and could help offset cuts at the federal level. In January, the federal budget called for Canada's three granting councils to scale back their budgets by Can $\$ 148$ million over three years, starting this year (see Nature 457, 646; 2009). It also failed to provide support to Genome Canada, a not-forprofit funding organization. In April, Genome Canada withdrew Can $\$ 18$ million from the International Regulome Consortium, a Can $\$ 80$ million Canadian-led research are not finding the opportunity to build their careers or support their teams are going to look at opportunities south of the border," says Tom Hudson, president and scientific director of the Ontario Institute for Cancer Research in Toronto. John Wilkinson, the Ontario minister of research and innovation, wants the fund to help retain scientists, he said in a statement. Ontario is Canada's largest biomedical research centre and the fourth largest in North America.

Winning projects are likely to be announced in early 2010. The funds will cover salaries, equipment and other research costs, and collaborations with international partners will receive priority. Winners will receive at least Can $\$ 3.5$ million and up to one-third of the project's cost, with the balance coming from institutional and private-sector partners.

\section{programme (see Nature 458, 819; 2009).}

The government has invested millions in science infrastructure, but many say that's not enough. "Canada has been overbuilding science infrastructure and under-supporting researchers and other workers," says Paul Hebert, director of the Biodiversity Institute of Ontario at the University of Guelph. Hebert, who is the driving force behind the International Barcode of Life project that is cataloguing genetic signatures, calls it an "important" and "timely" funding competition. Can $\$ 20,000$ for master's- and PhD-level graduate students and Can $\$ 50,000$ for postdoctoral fellows. "The best way to train postdocs and students is by having them be part of cutting-edge projects," says Hudson. Hannah Hoag The fund will cover salaries of up to

\section{POSTDOC JOURNAL}

\section{Interdisciplinary images}

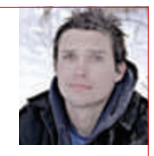

Live jazz music crashes through the dark bar as my friend and I discuss what it means to be 'interdisciplinary'. My beer-loosened words are barely audible over the music.

First, I say, we must define a discipline. I describe my experience as a postdoc. In my first position, I did experimental work in single-molecule biophysics, manipulating muscle proteins with laser tweezers. Perhaps a dozen labs use this method; notation convention that define the discipline.

My current position, they have a vocabulary and
I contend, is interdisciplinary. I use mathematical and mechanical models to understand biology. Some of this work addresses the same questions as my previous experimental work. However, for my current work, no single community of researchers exists. One community understands our mathematical methods but not the biological systems; another is familiar with the biology but not the maths.

Conducting research

that spans the expertise of two or more groups, yet is understandable to each, presents a challenge. Because researchers are often experts in a single discipline, reviewing interdisciplinary papers can be difficult. Yet it presents the fantastic opportunity to start a new discipline.

As the music swallows my final words, I look across the table at my friend, a new graduate student, and doubt wonder how she will define interdisciplinary when she becomes a postdoc. Sam Walcott is a postdoc in theoretical biophysics at Johns Hopkins University in Baltimore, Maryland. if I have been much help. I
IN BRIEF

Non-tenure on the rise

The proportion of full-time tenured and tenure-track faculty in the United States has declined since the late 1990s and higher-education institutions are relying more on non-tenured 'contingent' faculty members, according to a report by the American Federation of Teachers. The higher-education instructional workforce grew in the past decade along with rising enrolments, the report finds. But colleges and universities have increasingly turned to part-time and fulltime non-tenured faculty. From 1997 to 2007, full-time tenured and tenure-track faculty members declined from about a third of the instructional staff to slightly more than a quarter. A similar change was found in all sectors of higher education.

\section{Winding up}

A wind-technology testing centre in Boston, Massachusetts, is poised to become a magnet for engineering and technology research and development posts, according to Robert Keough, spokesman for the Massachusetts executive office of energy and environmental affairs. On 12 May, the US Department of Energy announced a \$25-million award in economic stimulus funding to the state to accelerate development of the centre. The Boston centre - the nation's first large-blade test facility - will analyse commercial-sized wind turbine blades more than 50 metres and up to 90 metres in length, Keough says. Ten technicians will work at the centre when construction is complete in 2010 and more job opportunities are likely, he says.

\section{Biotech funding rethink}

The biotechnology industry performed well in 2008 despite the worldwide economic downturn, but financial services firm Ernst \& Young warns that the industry has to find new ways to do business. Revenues of publicly traded biotech companies rose by an average of $12 \%$ worldwide in 2008 . But capital raised in Europe and the Americas was down by almost half from 2007, and funds raised through initial public offerings fell by 95\% for the period (see Nature 458, 1062; 2009). "Firms will need to establish more durable models for funding innovation," says Glen Giovannetti, Ernst \& Young's global biotechnology leader, on the company's website. 